\title{
The assessment of the influence of the Gumiton organomineral complex on the development of root rot and structural elements of the winter wheat yield
}

\author{
Aleksey Suslov ${ }^{1}$, Dimitry Sviridenk ${ }^{1}$, Vasiliy Mamayev ${ }^{2}$, Irina Sychiova ${ }^{2}$ \\ ${ }^{1}$ Russian Institute of Radiology and Agroecology (RIRAE) Obninsk, Kaluga region, Russia \\ ${ }^{2}$ Bryansk State Agrarian University, Bryansk, Russia, Russia
}

\begin{abstract}
It has been shown that pre-sowing treatment increases field germination by $5.5 \%$, and the preservation of plants after overwintering increases by $4.3 \%$. Gumiton strengthened the work of the assimilation apparatus of the flag leaf due to an increase in leaf area by $29.3-49.1 \%$ and extended the life of plants. As a part of a tank mixture (Tabu Super, $1.51 / \mathrm{t}+$ Tertia, $2.51 \mathrm{t}$ ), the drug allowed to reduce the prevalence of the root rot disease to $2.45-1.05 \%$ in comparison with the control. The organomineral complex provided the formation of a larger and more leveled grain with a mass of 1000 grains

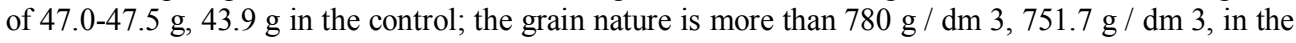
control. The use of Gumiton (seeds + tillering + piping) against the background of N $96 \mathrm{P} 96 \mathrm{~K} 96$ provided a high yield increase by $37.8 \%$. To reduce the expenses of foliar fertilization with nitrogen fertilizers, the Gumiton organic-mineral complex should be recommended, since it is an element of greening in intensive technologies of winter wheat cultivation.
\end{abstract}

Keywords: root rot, winter wheat, Gumiton organomineral complex, field germination, plant safety, productivity, crop structure.

\section{Introduction}

On the territory of the Russian Federation, root rot of plants is caused by several types of phytopathogenic fungi, the most widespread of which are Fusarium, Helminthosporium, Cercosporella and Ophiobolous root rot. In different ecological zones, certain types of pathogens predominate. In the climat conitions of Briansk region, in the process of the winter wheat such fungi as Fusarium (F.oxysporum Schl., F. avenaceum Sacc.) and Bipolaris sorokiana Shoem (Drechslera sorokiana Suram.et Jain, Helminthospoium sativum Pam.) were found.

Root rot can be found in almost every field. The intensity of their manifestation depends on weather conditions, predecessor, soil cultivation system, cultivar resistance and other factors. With a rapid development, yield losses can reach $10-30 \%$ or more [1].

Increasing the yield of winter wheat through the introduction of an element of greening against the background of the intensive use of a system of protective measures is an innovative technique. This method includes modern organo-mineral complexes. They help beneficial microorganisms to increase the cation exchange capacity (CEC), improve the water intake capacity, boost the micorrhizal competence of colonization and the supply of nutrients to the soil by changing the ph of it. As a result, the soil fertility increases and the productivity of agricultural crops increases $[2,3]$.
The experience of the development and practical application of innovative technologies for the cultivation of crops was reflected in the works of scientists from the Bryansk Agrarian University [4-8]. They provide for the use of biologically active substances of humate preparations and reduce the dose of nitrogen fertilizers by up to $40 \%$. Previously published materials [9-11] noted that organomineral complexes based on coprolite and peat activate growth processes in plants.

The Russian Institute of Radiology and Agroecology (RIRAE) has developed the drug Gumiton [12], which is an organomineral complex based on peat. It includes (wt\%): N - 12.0; P $205-23.0$; K $20-30.3$; organic matter - 20.1 (including water-soluble potassium humates - $14.1(25-40 \mathrm{~g} / 1)$; trace elements (B - 0.2\%; Mo - $0.1 \%$; $\mathrm{Mn}-0,1 \%$ ); oxides and salts of $\mathrm{Ca}, \mathrm{Mg}, \mathrm{Fe}$ (in the ash residue - 14.1).

The aim of the research is to study the influence of the Gumiton organomineral complex on the development of root rot and productivity of winter wheat in the conditions of the Bryansk region.

\section{Methodology for conducting research}

Experimental studies of the influence of plant protecting products and the Gumiton organomineral complex on the development of root rot were carried out in the field conditions in 2018-2019 at the experimental field of the Bryansk State Agrarian University. The soil is gray forest medium loamy, formed on loess-like calcareous loam. Agrochemical indicators are humus with the content of 
$3.6 \%, \mathrm{pH}_{\mathrm{KCl}} 5.6, \mathrm{P}_{2} \mathrm{O}_{5}$ with the content of $285-302 \mathrm{mg} / \mathrm{kg}$ soil, $\mathrm{K}_{2} \mathrm{O} 178-194 \mathrm{mg} / \mathrm{kg}$ soil. Winter wheat of the variety Moskovskaya 40 was selected as the object of the study; the seeding rate was 5.0 million pcs. germinating seeds / ha, the predecessor is the vetch-oat mixture. The area of the experimental plot is $60 \mathrm{~m} \mathrm{2}$, the replication is fourfold with a randomized placement. For sowing, elite seeds were used, which were treated with fungicidalinsecticidal preparations of the "August" company (Tabu Super $1.5 \mathrm{l} / \mathrm{t}+$ Tertium $2.5 \mathrm{l} / \mathrm{t}$ ). The determination of the prevalence and development of root rot was carried out in autumn after the mass emergence of seedlings, in spring (resumption of spring vegetation) in the phase of going into the tube, by visual route inspection and sampling according to generally accepted recommendations. To analyze the composition of pathocomplexes, fungi were isolated from the affected tissues into a pure culture on PGA followed by microscopy [13].

In the spring of 2018 , the plant was treated with a growth regulator (against lodging) Reggae 1 1/ha in a phase of 25-30 (according to the BBCH scale). In the general background, during the tillering and stemming phases, there were carried out such protective measures against weeds and pests as seed dressing against dicotyledonous weeds in the tillering phase up to the 2nd internode with the preparations Ballerina Super 0.5 1/ha + Eraser Extra 1 1/ha (in the phase 2-3 leaves against grass weeds).

The experimental scheme included the following options on a general background of $\mathrm{N}_{96} \mathrm{P}_{96} \mathrm{~K}_{96}$.

\begin{tabular}{|c|c|c|}
\hline \multicolumn{3}{|c|}{ Experimental options, timing and application rates } \\
\hline 1 & \multirow{5}{*}{$\begin{array}{c}\text { Background } \\
\mathrm{N}_{96} \mathrm{P}_{96} \mathrm{~K}_{96}\end{array}$} & $\begin{array}{l}\text { Control - seed treatment (Tabu } \\
\text { Super, } 1.51 / \mathrm{t}+\text { Tertia, } 2.51 / \mathrm{t})\end{array}$ \\
\hline 2 & & $\begin{array}{c}\text { Seed treatment (Tabu Super, } \\
1.51 / \mathrm{t}+\text { Tertia, } 2.51 / \mathrm{t}+ \\
\text { Humiton, } 1 \mathrm{l} / \mathrm{t})\end{array}$ \\
\hline 3 & & $\begin{array}{c}\text { Seed treatment (Tabu Super, } \\
1.51 / \mathrm{t}+\text { Tertium, } 2.51 / \mathrm{t})+ \\
\left(\mathrm{N}_{100}+\mathrm{N}_{60}\right)\end{array}$ \\
\hline 4 & & $\begin{array}{c}\text { Seed treatment (Tabu Super, } \\
1.51 / \mathrm{t}+\text { Tertia, } 2.51 / \mathrm{t}+ \\
\text { Gumiton, } 11 / \mathrm{t})+ \text { Gumiton, } 1 \\
\text { 1/ha (tillering phase) }\end{array}$ \\
\hline 5 & & $\begin{array}{l}\text { Seed treatment (Tabu Super, } \\
1.51 / \mathrm{t}+\text { Tertia, } 2.51 / \mathrm{t}+ \\
\text { Gumiton, } 11 / \mathrm{t})+ \text { Gumiton, } 1 \\
\text { 1/ha (tillering phase) }+ \\
\text { Gumiton, } 0.51 / \text { ha ( phase out } \\
\text { into the tube) }\end{array}$ \\
\hline
\end{tabular}
organomineral complex for vegetative plants in the tillering phase in the spring of $11 /$ ha (diluted with water at the rate of $3001 / \mathrm{ha}$ ) and in the phase of entering the tube - a dose of $0.5 \mathrm{l} / \mathrm{ha}$.

Under the planned grain yield of $8.0 \mathrm{t} / \mathrm{ha}$, locally before sowing, Azofoska was introduced at the rate of $\mathrm{N}_{96} \mathrm{P}_{96} \mathrm{~K}_{96}$ (background) by the SZT-3.6 seeder. In the spring, two additional fertilizing with ammonium nitrate (34.5\%) were carried out: $\mathrm{N}_{100}$ during the resumption of the spring vegetation and $\mathrm{N}_{60}$ in the phase of the beginning of the tube.
The economic yield was taken into account by a continuous plot method using a selection combine harvester SR2010 TERRION, with a conversion to $14 \%$ moisture and $100 \%$ purity. The commodity assessment of the quality of grain was carried out by the weight of 1000 seeds and the nature of the grain $\mathrm{g} / \mathrm{dm} 3$. The planning of experiments and the analysis of the structure of the yield after harvesting wheat was carried out according to B.A. Dospekhov. The mathematical processing of the experimental data was carried out using the Microsoft Excel 2007 program with a 95\% significance level of the results.

The meteorological conditions of the research carried out in 2017-2018 and in 2018-2019 were characterized by temperature fluctuations, uneven precipitation in the form of rain, both in autumn and spring-summer periods, which influenced the infestation by root rot and the formation of the crop.

The autumn periods of 2017 and 2018 in terms of temperature indicators were close to the average longterm values, the amount of atmospheric precipitation in these years was only $75 \%$ of the norm, autumn 2018 turned out to be arid. The spring-summer growing season of 2018 turned out to be atypical for the region. Increased temperatures in May, lack of precipitation, strong winds lasting more than 20 days caused soil drought. June and July were rainy and cool. The amount of atmospheric precipitation in June was $73.1 \mathrm{~mm}$, the largest amount fell on July (162 mm), exceeding long-term values, August was dry. The resumption of spring vegetation in 2019 was very early (first decade of March) and rapid. April was warm, May was rainy, July was cool and humid. These weather and climatic factors influenced the incidence of root rot and increased the development and prevalence of the disease. The formation and filling of wheat grain in these years took place in conditions of high humidity.

One of the most important indicators of meteorological conditions is the hydrothermal coefficient, which characterizes the moisture and heat supply of crops. According to literary sources, SCC is optimal if its value is in the range from $1-1.5$, excessive is more than 1.6 and insufficient is less than 1 and weak - less than 0.5. The SCC value in August 2017 was characterized as insufficient (0.64), and in 2018 it was weak - only 0.22 (Table 1). In July, excessive waterlogging was observed (1.76 2.55), and in June - the optimal value of the indicator which was 1.02-1.37.

Table 1. Hydrothermal coefficient of the growing season of winter wheat 2017 - 2019

\begin{tabular}{|c|c|c|c|c|c|c|c|}
\hline \multirow{2}{*}{ Years } & \multicolumn{7}{|c|}{ Hydrothermal coefficient (HTC) } \\
\cline { 2 - 8 } & $\begin{array}{c}\text { Aug } \\
\text { ust }\end{array}$ & $\begin{array}{c}\text { Septe } \\
\text { mber }\end{array}$ & $\begin{array}{c}\text { M } \\
\text { ay }\end{array}$ & $\begin{array}{c}\text { Ju } \\
\text { ne }\end{array}$ & $\begin{array}{c}\text { Jul } \\
\text { y }\end{array}$ & $\begin{array}{c}\text { Aug } \\
\text { ust }\end{array}$ & $\begin{array}{c}\text { y- } \\
\text { Jul } \\
\text { y }\end{array}$ \\
\hline $\begin{array}{c}2017- \\
2018\end{array}$ & 0,64 & 2,8 & $\begin{array}{c}0,4 \\
1\end{array}$ & $\begin{array}{c}1,3 \\
7\end{array}$ & $\begin{array}{c}2, \\
55\end{array}$ & 0,22 & $\begin{array}{c}1,3 \\
8\end{array}$ \\
\hline $\begin{array}{c}2018- \\
2019\end{array}$ & 0,22 & 0,8 & $\begin{array}{c}2,1 \\
9\end{array}$ & $\begin{array}{c}1,0 \\
2\end{array}$ & $\begin{array}{c}1, \\
76\end{array}$ & 0,60 & $\begin{array}{c}1,1 \\
3\end{array}$ \\
\hline $\begin{array}{c}\text { Aver } \\
\text { age }\end{array}$ & 0,9 & 1,1 & 1,5 & 1,3 & $\begin{array}{c}1, \\
4\end{array}$ & 1,2 & $\begin{array}{c}1,3 \\
0\end{array}$ \\
\hline
\end{tabular}




\section{long-}

term

The effectiveness of the Gumiton organo-mineral complex and remedies for the development of root rot was studied under conditions of insufficient and excessive moisture in combination with a contrasting temperature regime.

\section{Results of the researches and their discussion}

The development of the disease is characterized by the way the pathogen spreads and the time of its reproduction. Moreover, the main reason limiting the spread of diseases transmitted through soil and seeds is often the amount of inoculum, although environmental conditions during infection can affect the intensity of symptoms. Conversely, the disease cannot develop even with an appropriate airborne inoculum, if climatic conditions are not conducive to infection. Fungicidal seed treatment sharply reduces the development of root rot pathogens and contributes to an increase in seed germination, improvement of winter crops overwintering, and the use of fertilizers when using fungicides is a kind of anti-stress factor that works to enhance the action of fungicides.

Sowing of winter wheat was carried out at the onset of favorable weather conditions at the beginning of the second decade of September. This was due to the lack of precipitation in late August and early September during the study years. In case of using Gumiton, the plants appeared two days earlier. It was found that the use of a fungicidal-insecticidal dressing agent together with Gumiton at a dose of $11 / \mathrm{t}$ reduced the root rot infestation and increased the field germination of winter wheat. Plants had had 5-6 leaves before leaving for winter, and 3-4 leaves were formed in the control. The treated plants tolerated overwintering better. The number of stems during the treatment of seeds with Gumiton, on average, exceeded the control variant by 5.5 percentage points and amounted to 446 units (Table 2).

Table 2. Field germination and overwintering of winter wheat using Gumiton

\begin{tabular}{|c|c|c|c|c|c|c|}
\hline \multirow[b]{2}{*}{ Options } & \multicolumn{3}{|c|}{ Shoots } & \multicolumn{3}{|c|}{ Wintering } \\
\hline & $\begin{array}{c}201 \\
7\end{array}$ & $\begin{array}{c}201 \\
8\end{array}$ & $\begin{array}{c}\text { averag } \\
\mathrm{e}\end{array}$ & $\begin{array}{c}201 \\
8\end{array}$ & $\begin{array}{c}201 \\
9\end{array}$ & $\begin{array}{c}\text { averag } \\
\mathrm{e}\end{array}$ \\
\hline $\begin{array}{c}\text { Tabu } \\
\text { Super, } \\
1.51 / \mathrm{t}+ \\
\text { Tertia, } \\
2.5 \mathrm{l} / \mathrm{t})\end{array}$ & $\begin{array}{c}\frac{422}{84} \\
4\end{array}$ & $\begin{array}{c}\frac{423}{84} \\
7\end{array}$ & $\frac{418}{83,5}$ & $\begin{array}{c}\frac{370}{87} \\
6\end{array}$ & $\begin{array}{c}\frac{368}{89} \\
3\end{array}$ & $\frac{369}{88,5}$ \\
\hline $\begin{array}{c}\text { Tabu } \\
\text { Super, } \\
1.51 / \mathrm{t}+ \\
\text { Tertia, } \\
2.51 / \mathrm{t}+ \\
\text { Humito } \\
\mathrm{n}, 11 / \mathrm{t}\end{array}$ & $\begin{array}{c}\frac{441}{88,} \\
2\end{array}$ & $\begin{array}{c}\frac{450}{90} \\
0\end{array}$ & $\frac{446}{89,1}$ & $\begin{array}{c}\frac{406}{92} \\
1\end{array}$ & $\begin{array}{c}\frac{421}{93} \\
5\end{array}$ & $\frac{414}{92,8}$ \\
\hline LDS, 05 & $\begin{array}{c}12 \\
4 \\
\end{array}$ & $\begin{array}{c}20 \\
6 \\
\end{array}$ & & $\begin{array}{c}24 \\
3 \\
\end{array}$ & $\begin{array}{c}25 \\
7 \\
\end{array}$ & \\
\hline
\end{tabular}

Note: in the numerator - the number of plants, pcs $/ \mathrm{m}^{2}$, in the denominator $-\%$

The spring registration of the stand density (BBB) showed a positive effect of the preparation on the overwintering of plants. There was an increase in overwintered plants up to $92.8 \%$ and a decrease in the infestation by root rot of winter wheat by $1.9 \%$ relative to the control.

In the phase of resumption of spring tillering, the first treatment of plants with a tank mixture was carried out (Ballerina Super, 0.5 1/ ha + Eraser Extra, 1 1/ ha + Gumiton, $11 / \mathrm{ha}$ ), and the second - in the phase of entering the tube with a dose of Humiton $0,51 /$ ha. The introduction of Gumiton into the composition of tank mixtures reduces the infestation by root rot (Fig. 1) to the heading phase.



Fig. 1. Assessment of the development $(\mathrm{R}, \%)$ and prevalence $(\mathrm{P}, \%)$ of root rot when using

Gumiton in tank mixtures (experimental field of the Bryansk State Agrarian University, 2018-2019)

In the works of O.S. Bezuglova et al. $[14,15]$ it is indicated that plants developing under the influence of humic substances are able to more actively regulate the processes of phosphorus mobilization. By the phase of the onset of heading, the prevalence of the disease decreased from $4.32 \%$ in the control to $2.45-1.05 \%$ in the treatment when treated with Gumiton as part of a tank mixture (Tabu Super, $1.51 / \mathrm{t}+$ Tertium, $2.51 / \mathrm{t}$ ).

The organomineral complex in the composition of the tank mixture acted as a factor inhibiting to a certain extent the process of development and spread of root rot. Treatment of seeds and double sowing with the studied drug is more expedient than treatment of seeds, the highest biological efficiency which was noted is $80.1 \%$, and when processing seeds, it was $76.2 \%$.

The similar results on the suppression of the development of phytopathogenic microflora in the root zone of plants when using humic preparations were obtained by other researchers, too. In particular, suppression of root rot caused by pathogenic fungi such as F. oxysporum in asparagus [16], Rhizoctonia solani in cucumber, and Phytophthora sp. in red oak [17] was noticed.

The humic preparation plays its role as an inhibitory factor on the spread of diseases in the process of plant development and contributes to an increase in the disease resistance of winter wheat plants.

Scientific publications indicate that humic substances affect respiration and photosynthesis, stimulate root growth and branching, activate the absorption of nutrients, and increase the efficiency of nutrient use [1821]. 
As a result of the increase in the incoming nutrients, the growth of the vegetative apparatus is activated. The dominant role in the phase of formation and maturation of caryopses in the process of photosynthesis belongs to the assimilating surface of the two upper leaves. They actively work not for the plant, but for the formation harvest of caryopses. It has been established that due to the long life span and an increase in the area of the flag leaf, about $40 \%$ of the grain yield is formed [22, 23].

The assessment of the linear size of the flag leaf was carried out in the heading phase, on the main shoot; the leaf area was calculated using a coefficient of 0.67 .

The studied drug will allow the formation of a larger flag leaf both in length and in width in comparison with the control variant. On the control, the length and width of the leaves averaged 21.4 and $1.1 \mathrm{~cm}$, respectively, and the leaf area was $1 \quad 5.7 \mathrm{~cm}^{2}$. In variant 3 with mineral fertilizers (N96P96K96 + N100 + N60), the flag leaf formed an area of $20.9 \mathrm{~cm}^{2}$ (length $-24.8 \mathrm{~cm}$ and width $1.26 \mathrm{~cm})$. The double application of Gumiton during the growing season made it possible to form an area of the flag leaf of $23.4 \mathrm{~cm}^{2}$ (length $26.3 \mathrm{~cm}$, width $-1.33 \mathrm{~cm}$ ), and a single application with the use of mineral fertilizer in the tillering phase at the level of option 3. In variants 4 and 5, Gumiton enhanced the work of the assimilation apparatus of the flag leaf by increasing the leaf surface by $29.3-49.1 \%$ and extending the lifespan. The plants had a dark green color. Its double application in option 5 in conditions of higher precipitation (July 2018) it increased the growing season and an extended the area of the flag leaf in options 4 and 5, in comparison with the conditions of 2019.

Table 3. The influence of the Gumiton organo-mineral complex on the average value of the structure of the winter wheat yield and its efficiency (2018-2019)

\begin{tabular}{|c|c|c|c|c|c|}
\hline Variant & Option & Option & Option & Option & Option \\
\hline $\begin{array}{c}\text { The } \\
\text { number of } \\
\text { grains per } \\
\text { ear, pcs. }\end{array}$ & 27,1 & $\frac{28,5}{5,2}$ & $\frac{29,9}{10,3}$ & $\frac{30,1}{11,1}$ & $\frac{30,2}{11,4}$ \\
\hline $\begin{array}{c}\text { Weight of } \\
1000 \\
\text { grains, gr }\end{array}$ & 43,9 & $\frac{44,2}{0,7}$ & $\frac{47,4}{8,0}$ & $\frac{47,0}{7,1}$ & $\frac{47,5}{8,2}$ \\
\hline $\begin{array}{c}\text { Number } \\
\text { of } \\
\text { productive } \\
\text { stems, } \\
\text { pcs/m }\end{array}$ & 548,5 & $\frac{591,5}{7,8}$ & $\frac{592,5}{8,0}$ & $\frac{617,0}{12,5}$ & $\frac{627,0}{14,3}$ \\
\hline $\begin{array}{c}\text { Flag leaf's } \\
\text { area, cm }\end{array}$ & 15,7 & $\frac{16,1}{2,5}$ & $\frac{20,9}{33,1}$ & $\frac{20,3}{29,3}$ & $\frac{23,4}{49,1}$ \\
\hline $\begin{array}{c}\text { Biological } \\
\text { yield, } \\
\text { g/m } \text { m }^{2}\end{array}$ & 651,1 & $\frac{741,2}{13,8}$ & $\frac{837,7}{28,7}$ & $\frac{871,8}{33,9}$ & $\frac{896,9}{37,8}$ \\
\hline $\begin{array}{c}\text { Nature, } \\
\mathrm{g} / \text { dm }^{3}\end{array}$ & 751,7 & $\frac{767,3}{2,1}$ & $\frac{780,9}{3,9}$ & $\frac{783,1}{4,0}$ & $\frac{788,0}{4,8}$ \\
\hline
\end{tabular}

Note: the numerator is the average over two years, the denominator is efficiency in terms of the share of positive influence to control, $\%$

The treatment of seeds with Gumiton contributed to an increase in the formation of productive stems by $7.8 \%$ relative to the control, and the treatment of plants during the growing season allowed them to increase and preserve up to $14.3 \%$.

On average, during two years the largest number of productive stems on the background of N96P96K96 was noted in options 5 and 6 . Treatment of seeds and application of fertilizing with mineral fertilizers (option 3 ) equally influenced the formation of productive stems.

The treatment of plants during the growing season with Gumiton ensured the formation of a larger and more uniformed grain. The weight of 1000 grains in options 4 and 5 was $47.0-47.5 \mathrm{~g}$ and $43.9 \mathrm{~g}$ in the control; the number of grains in an ear was 30.2 pieces and 27.1 pieces in the control; grain nature is more than $780 \mathrm{~g} / \mathrm{dm}^{3}$, and $751.7 \mathrm{~g} / \mathrm{dm}^{3}$ in control (Table 3 ).

The application of Gumiton three times (in seeds + tillering + output into the tube phases) against the background of N96P96K96 is the most expedient, while with a single (in the seeds phase) or double (in seeds + tillering phases) application the highest yield increase was $37.8 \%$. It was obtained due to the higher grain content, grain weight per ear and the formed number of productive shoots and averaged $896 \mathrm{~g} / \mathrm{m}^{2}$.

The highest increase in grain due to the use of the Gumiton drug in the form of foliar application was obtained in arid 2018. This effect was noted by L.A. Khristeva, pointing out the positive impact of humic acids on the resistance of plants to unfavorable weather conditions with a decrease in the ability of the root system to assimilate and in the adjustment of the nutrition with macro and microelements [24].

Thus, seed treatment and two-fold application of the Gumiton drug to the wheat plants during the growing season contributed to the formation of a larger number of grains, prolongation of the life of the assimilation apparatus, better accumulation of assimilates and seed filling capacity. Researches demonstrate the increase in the wheat grain productivity up to $9 \%$ relative to option 3 (N96P96K96 + N100 + N60) due to foliar treatment of plants with the Gumiton organomineral complex.

Conclusion. The inclusion of the organic-mineral complex Gumiton in the technology of winter wheat cultivation (seed treatment + two foliar dressings: tillering and heading) against the background of N96P96K96 allows to get the most multifunctional effect. Fungistatic effect of reducing the prevalence of the disease from $4.32 \%$ in control to $2.45-1.05 \%$ when treated with Gumiton (using Tabu Super, $1.51 / \mathrm{t}+$ Tertium, $2.51 / \mathrm{t}$ ) in different phases of development culture. The increase in the grain yield of winter wheat, depending on the intake, varied from $204 \mathrm{~g} / \mathrm{m}^{2}$. (2019) to $288 \mathrm{~g} / \mathrm{m}^{2}$. (2018), respectively. The increase in yield occurred due to the increase in productive stems, the number of grains per ear and the mass of 1000 grains.

The combination of methods of using the Gumiton preparation against the background of the main mineral nutrition should be considered as an additional means of biological correction of plant nutrition in stressful meteorological conditions to reduce the infestation by root rot. 


\section{References}

1. 1.Pidoplitschko N.M. Mushrooms are parasites of cultivated plants. Determinant. T.2. Mushrooms are imperfect. Kiev: Scientific thought1997. 300 c.

2. 2.Atkinson CJ, Fitzgerald JD, Hipps NA. Potential mechanisms for achieving agricultural benefits from biochar application to temperate soils: A review. Plant soil. 2010;337:1-8.

3. Hossain MK, Strezov V, Chan KY, Ziolkowski A, Nelson PF. Influence of pyrolysis temperature on production and nutrient properties of wastewater sludge biochar. J Environ Manag. 2011; 92(1):223228

4. Torikov V.E., Melnikova O.V., Shpilev N.S., Mameev V.V., Osipov A.A. Yield and grain quality of modern winter wheat varieties in the south-west of the Central region of Russia//Fruit growing and berry growing of Russia 2017, V. 48, №1. P . 260267.

5. Torikov V.E., Melnikova O.V., Mameev V.V., Torikov V.V., Osipov A.A. Influence of the fertilizer system on the agrobiological properties of soil, yield, raw gluten content, amino acid and elemental composition of soft winter wheat grains//Bulletin of the Izhevsk State Agricultural Academy, 2016, №1(46). P . 8-20.

6. Torikov V.E., Osipov A.A. Influence of mineral fertilizers on the yield and quality of winter wheat grains//Agrochemical bulletin, 2015, № 5. P. 7-9.

7. Kotikov M.V., Melnikova O.V., Mazhugo T.M. The action is humistic on the yield of grain crops and potatoes//Agrochemical bulletin.2009. № 3. P. 36-38

8. Melnikova O.V., Mazhugo T.M. The influence of terraflex and albite on the yield and quality of spring wheat grains//Bulletin of the Bryansk State Agricultural Academy 2015. № 3-1. P. 6-10.

9. Mameev V.V. Effectiveness of coprolite in cultivating vegetable crops//Agrochemical bulletin. 2009. № 3. P. 38-40

10. Ratnikov A.N., Sanzharova N.I., Suslov A.A., Sviridenko D.G., Popova G.I., Petrov K.V., Ivankin N.G., Prudnikov P.V. Peat - the basis for the production of a highly effective organomineral complex GEOTON // Bulletin of the Bryansk State Agricultural Academy, 2018, № 3(67). P. 24-28.

11. 11Ratnikov A.N., Popova G.I., Sviridenko D.G., Arysheva S.P., Suslov A.A., Petrov K.V., Balanova O.Yu., Lashkib N.A., Mazurov V.N., Semeshkina P.S., Dadaeva T.A.. Efficiency of Application of the New GEOTON Organo-Mineral Complex in the Cultivation of Cereals and Maize // Bulletin of Agrarian Science 2018, № 3(72). P. 74-82.

12. Patent for invention No. 2709737 "Biologically active organ-mineral complex and method of its production (authors - Sanzharova N.I., Petrov K.V., Ratnikov A.N., Sviridenko D.G., Suslov A.A., Ivanov I.A., Ivankin N.G.). Description of the invention to the patent. Newsletter. № 35 19.12.19. $6 \mathrm{p}$.

13. Pidoplitschko N.M. Mushrooms are parasites of cultivated plants. Determinant. T.2. Mushrooms are imperfect. Kiev: Scientific thought, 1997. 300 p.
14. Bezuglova O.S., Polienko E.A., Gorovtsov A.V., Lykhman V.A. Use of humic fertilizer bio-don on common chernozem for winter wheat//Theoretical and applied ecology 2015. №1. P. 89-95.

15. Polienko E.A., Naimi O.I., Bezuglova O.S. The influence of the humic drug BIO-Don on the composition and dynamics of nutrient elements in the soil-plant system // News of the Orenburg State Agrarian University. 2017. №5(67). P. 192-195.

16. Elmer WH, Pignatello JJ. Effect of biochar amendments on mycorrhizal associations and Fusarium crown and root rot of asparagus in replant soils. Plant Dis. 2011;5(8):960-966

17. Zwart DC, Kim SH. Biochar amendment increases resistance to stem lesions caused by Phytophthora spp. in tree seedlings. Hort Sci. 2012;47(12):17361740

18. Nardi, S.; Pizzeghello, D.; Muscolo, A.; Vianello, A. Physiological effects of humic substances on higher plants. Soil Biol. Biochem. 2002, 34, 1527-1536. [CrossRef]

19. Trevisan, S.; Francioso, O.; Quaggiotti, S.; Nardi, S. Humic substances biological activity at the plant-soil interface. Plant Signal. Behav. 2010, 5, 635-643. [CrossRef]

20. Canellas, L.; Olivares, F.; Aguiar, N.; Jones, D.; Nebioso, A.; Mazzei, P.; Piccolo, A. Humic and fulvic acids as biostimulants in horticulture. Sci. Hortic. 2015, 196, 15-27. [CrossRef]

21. Canellas, L.; Olivares, F. Physiological responses to humic substances as plant growth promoter. Chem. Biol. Technol. Agric. 2014, 1, 3. [CrossRef]

22. Shatilov I.S., Zamaraev A.G., Chapovskaya G.V. Formation and productivity of the photosynthetic apparatus of agricultural plants in crop rotation // News of the Timiryazev Agricultural Academy. 1969. Publication. 6. P. 18-26.

23. Nichiporovich A.A. Physiology of photosynthesis and plant productivity // Physiology of photosynthesis. M., 1982. P. 7-34.

24. Hristeva L.A. Action of physiologically active humic acids on plants under adverse external conditions//Humic fertilizers: theory and practice of their application. Dnipropetrovsk , 1973, V.4, p.1523. 